\title{
Podatność osuwiskowa Polski
}

\author{
Tomasz Wojciechowski ${ }^{1}$
}

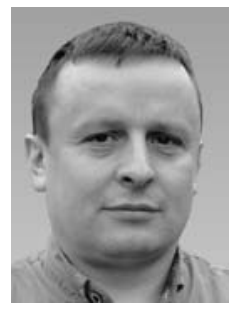

Landslide susceptibility of Poland. Prz. Geol., 67: 320-325; doi: 10.7306/2019.25

A b s tra ct. Using the location data of landslides and information on geo-environmental conditions, the landslide susceptibility in Poland was calculated using statistical methods. It shows that $15 \%$ of the country's area is susceptible to landslides. The greatest threats occur in the Carpathians and in many regions of the Sudetes, uplands and in the riverbanks. The most vulnerable areas are the slopes in the range of 9-30, which are built by the flysch sediments in the faulted zones. The areas susceptible to landslides include over a million buildings and about 7,000 km of roads.

Keywords: landslides, landslide susceptibility, Poland

Usytuowanie osuwisk jest ściśle uwarunkowane zespołem czynników, od których jest uzależniona stateczność stoków (Bober, 1984; Bober i in., 1997; Zabuski i in., 1999). Są one nazywane czynnikami biernymi. Spośród nich należy wyróżnić warunki geologiczne (litologiczne i tektoniczne), morfologiczne (np. spadki, ekspozycję i kształt stoku), hydrologiczne i hydrogeologiczne oraz pokrycie terenu. Gdy współoddziaływanie czynników biernych stwarza warunki odpowiednie do powstania osuwiska, jego uruchomienie może nastąpić pod wpływem impulsu, którym w Polsce najczęściej są opady atmosferyczne, erozja rzeczna lub morska, rzadziej wstrząsy sejsmiczne czy działalność człowieka (ryc. 1). Impulsy te są nazywane czynnikami aktywnymi. Najbardziej podatne na ruchy masowe są miejsca, gdzie ruchy takie zachodziły już wcześniej. Informacje o zespole czynników biernych, charakterystycznych dla określonych obszarów, można ekstrapolować za pomocą metod statystycznych na większy obszar i otrzymać mapę podatności osuwiskowej. Mapę taką należy odczytywać jako obraz możliwości wystąpienia osuwisk na danym obszarze ze względu na panujące tam warunki środowiskowe.

W skali świata i Europy Polska jest zazwyczaj określana jako kraj mało podatny na procesy osuwiskowe. Na ogólnoeuropejskiej mapie podatności osuwiskowej (Van den Eeckhaut i in., 2012) w większości została oznaczona jako obszar bardzo mało podatny osuwiskowo, z niewielkim udziałem procentowym powierzchni o małej podatności na osuwiska. Jedynie na terenie Karpat i w części Sudetów podatność osuwiskową określono jako średnią, a miejscami dużą. Ciekawostką na tej mapie są Żuławy Wiślane, ocenione jako bardziej podatne osuwiskowo od zboczy doliny Wisły, na których osuwiska nie należą do rzadkości. Podobnie Polska prezentuje się na Europejskiej mapie podatności osuwiskowej wykonanej w ramach projektu ELSUS1000 (European Landslide Susceptibility Map).

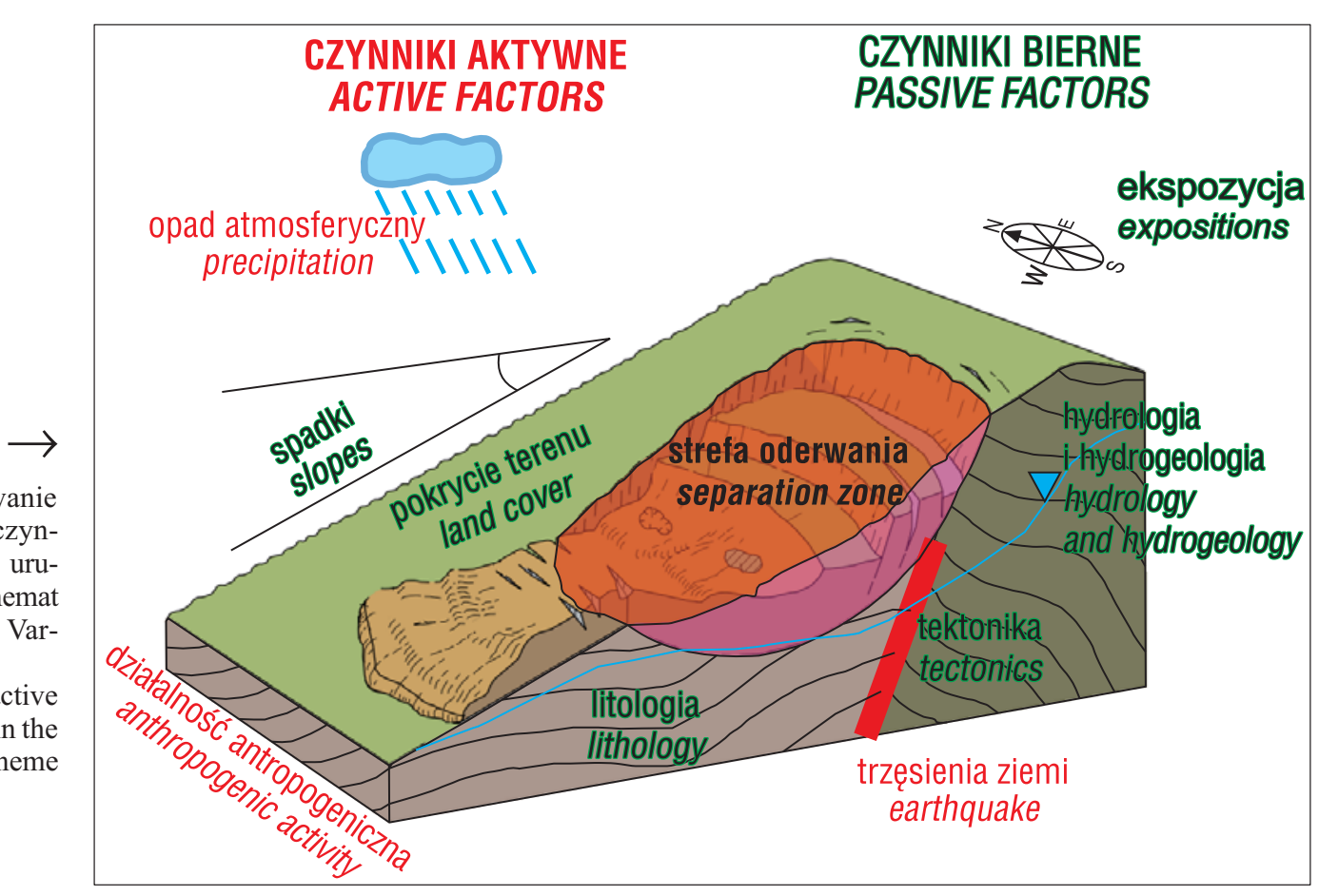

Ryc. 1. Współwystępowanie aktywnych i biernych czynników warunkujących uruchomienie osuwiska. Schemat osuwiska na podstawie Varnes (1978)

Fig. 1. Co-existence of active and passive factors within the landslide. Landslide scheme based on Varnes (1978)

\footnotetext{
${ }^{1}$ Państwowy Instytut Geologiczny - Państwowy Instytut Badawczy, Centrum Geozagrożeń, ul. Skrzatów 1, 31-560 Kraków; twoj@pgi.gov.pl
} 
Na pierwszej wersji tej mapy z roku 2014 (Günther i in.) pojawia się więcej miejsc podatnych na osuwiska, głównie w części północnej, jednak dolina Wisły oraz Karpaty w dalszym ciagu są niedoszacowane, a region Pogórza Dynowskiego, gdzie zarejestrowano już tysiące osuwisk (Rubinkiewicz i in., 2015), został sklasyfikowany jako mało podatny na osunięcia. Zdecydowanie lepiej podatność osuwiskową Polski wizualizuje druga wersja mapy, wykonana w ramach tego samego projektu w roku 2018 (Wilde i in., 2018), na której Karpaty są już przedstawiane jako bardzo podatne osuwiskowo, a dolina Wisły jako mało podatna. Większą podatnością charakteryzują się Wyżyny Kielecka i Lubelska. Niedoszacowanie problemów ruchów masowych w Polsce jest widoczne również w innych pracach, w których na obszarze Polski jedynie Karpaty przejawiają tendencje osuwiskowe (Nadim i in., 2006; Hong i in., 2007; WHO, 2010; Kirschbaum, Stanley, 2018).

Jeszcze kilka lat temu świadomość zagrożenia osuwiskowego w Polsce ograniczała problem ruchów masowych do Karpat fliszowych. Istniała, co prawda, wiedza o występowaniu pojedynczych osuwisk w Polsce pozakarpackiej, jednak skala problemu nie została, jak dotąd, całościowo określona. Podatność osuwiskowa w Polsce była dotychczas obliczana tylko dla Karpat (Długosz, 2011; Holec i in., 2013) lub regionalnie dla wybranych, jeszcze mniejszych obszarów (Mrozek i in., 2004, 2016; Mrozek, 2013; Kamiński, 2007, 2012; Wojciechowski, 2008, 2010; Małka, 2015; Wojciechowski, Wójcik, 2015; Kamieniarz i in., 2016; Bronowski i in., 2016; Pawluszek, Borkowski, 2017; Sikora i in., 2017). Na podstawie wyników rejestracji osuwisk z lat 1968-1970 oraz materiałów Oddziału Karpackiego PIG w 2007 r. Rączkowski opracował (na potrzeby V Międzynarodowych Targów Geologicznych) mapę przedstawiającą rozmieszczenie obszarów zagrożonych ruchami masowymi na terenie całej Polski (https://www.pgi.gov.pl/krakow/oddzial-karpacki/sep1-kr ak/karpackie-osuwiska.html). Pod redakcją Grabowskiego (2008) opracowano również Mapę obszarów predysponowanych do ruchów masowych na obszarze pozakarpackim, bazująca głównie na materiałach archiwalnych i analizach topograficznych. Były to jednak opracowania eksperckie, opierające się na ograniczonych danych.

Świadomość osuwiskowa w Polsce podnosi się głównie za sprawą realizowanego Systemu Osłony Przeciwosuwiskowej (SOPO), który obejmuje swoim zasięgiem obszar całego kraju. Prowadzona za pomocą jednolitej i spójnej metody inwentaryzacja osuwisk (Grabowski i in., 2008) z każdym dniem realizacji projektu SOPO dostarcza coraz bardziej szczegółowego obrazu Polski pod względem zagrożeń osuwiskowych.

Podatność osuwiskową Polski po raz pierwszy obliczono w 2015 r., na potrzeby Ogólnopolskiej Konferencji O!suwisko w Wieliczce. Wykorzystano do tego celu dane zawarte w bazie danych SOPO i na ich podstawie wykonano mapę, która ukazała przestrzenne zróżnicowanie prawdopodobieństwa wystąpienia ruchów osuwiskowych na obszarze całego kraju (Wojciechowski i in., 2015). Drugą wersję tej mapy zaprezentowano na 6. Ogólnopolskim Sympozjum Współczesne Problemy Geologii Inżynierskiej w Rzeszowie (Wojciechowski i in., 2017). W niniej- szym artykule opisano trzecią już wersję Mapy podatności osuwiskowej Polski (ryc. 2).

\section{SYSTEM OSLONY PRZECIWOSUWISKOWEJ (SOPO) - DANE O OSUWISKACH}

Pod koniec 2018 r. baza danych SOPO (mapa.osuwiska.pgi.gov.pl) zawierała kompletne dane o prawie 62 tys. osuwisk, które powstały zarówno na stokach górskich, zboczach dolin rzecznych, skarpach przykorytowych i klifach, jak również na skłonach obiektów antropogenicznych. W czasie kartowania geologicznego 38\% spośród tych osuwisk zakwalifikowano jako aktywne i okresowo aktywne. Należy jednak mieć na uwadze, że udział osuwisk aktywnych może być obecnie większy, albowiem ruchy masowe należą do zjawisk dynamicznie zmiennych w czasie, a część prac wykonano przed tzw. katastrofą osuwiskową z 2010 r., w wyniku której uaktywniły się tysiące osuwisk.

Najwięcej ruchów masowych i związanych z nimi zagrożeń występuje w Karpatach (Poprawa, Rączkowski, 2003; Rączkowski, 2007; Wójcik i in., 2017), przyczyniając się do poważnych strat materialnych. $Z$ tego też powodu główny nacisk na prace kartograficzne kładziono, jak dotąd, w województwach śląskim, małopolskim i podkarpackim. Obecny stan rozpoznania pozwala szacować, że w Polsce może występować ponad 100000 osuwisk (Wójcik, Wojciechowski, 2016).

\section{ŹRÓDLA DANYCH}

W celu obliczenia podatności osuwiskowej Polski zebrano dane o ośmiu czynnikach biernych, których współwystępowanie warunkuje powstawanie osuwisk (tab. 1). Za pomocą systemu informacji geograficznej (geographic information system - GIS) wszystkie dane ujednolicono do wspólnej georeferencji, przyjmując Państwowy Układ Współrzędnych Geodezyjnych PL-1992 oraz oczko siatki obliczeniowej $50 \times 50 \mathrm{~m}$. Zmienne objaśniające (tj. predyktory) wyrażane danymi ciagłymi, np. spadki, ekspozycja, odległości czy wysokości, sklasyfikowano w odpowiednich przedziałach, uzyskując atrybuty danych dyskretnych. Dane odnośnie litostratygrafii i tektoniki pozyskano z Mapy geologicznej Polski w skali 1:500 000 (Marks i in., 2006). Tektonikę wyrażono w postaci buforu odległości do struktur nieciagłych, ograniczając dystans oddziaływania do $2000 \mathrm{~m}$.

W celu wyliczenia atrybutów topograficznych obszaru badań, takich jak spadki, ekspozycja stoku i wysokość względem poziomu morza, utworzono jednolity numeryczny model terenu (NMT). Do konstrukcji tego modelu wykorzystano głównie dane wysokościowe pochodzące z Państwowego Zasobu Geodezyjnego i Kartograficznego (PZGiK). Zostały one zebrane w ramach projektów ISOK (Informatyczny System Osłony Kraju) i CAPAP (Centrum Analiz Przestrzennych Administracji Publicznej) metoda lotniczego skanowania laserowego. W celu uzyskania pełnego pokrycia terenu do interpretacji obszarów nie objętych skanowaniem lotniczym wykorzystano wysokościowe dane radarowe pozyskane w trakcie satelitarnej misji SRTM (Shuttle Radar Topography Mission).

Odległość od cieków i zbiorników wodnych obliczono na podstawie Mapy Podziału Hydrograficznego Polski w 
Tab. 1. Źródła danych o biernych czynnikach powstawania osuwisk

Table 2. Data sources of passive factors leading to formation of landslides

\begin{tabular}{|c|c|}
\hline $\begin{array}{l}\text { Czynnik bierny } \\
\text { Passive factor }\end{array}$ & $\begin{array}{l}\text { Źródło danych } \\
\text { Data source }\end{array}$ \\
\hline Litostratygrafia / Lithostratigraphy & \multirow{2}{*}{$\begin{array}{l}\text { Mapa geologiczna Polski w skali 1:500 } 000 \text { (Marks i in., 2006) } \\
\text { Geological map of Poland at a scale of 1: } 500000 \text { (Marks et al., 2006) }\end{array}$} \\
\hline Odległość od uskoków / Distance from faults & \\
\hline Spadki terenu / Slopes & \multirow{3}{*}{$\begin{array}{l}\text { Numeryczny model terenu obliczony na podstawie danych LiDAR i SRTM } \\
\text { Numerical model of the area calculated based on the LiDAR and SRTM data }\end{array}$} \\
\hline Ekspozycja stoków / Exposition of the slopes & \\
\hline Wysokość n.p.m. / Height above sea-level & \\
\hline $\begin{array}{l}\text { Odległość od cieków i zbiorników wodnych } \\
\text { Distance from watercourses and water reservoirs }\end{array}$ & $\begin{array}{l}\text { Mapa Podziatu Hydrograficznego Polski w skali 1:10 } 000 \text { (PGW WP) } \\
\text { Map of the Hydrographical Division of Poland at a scale of 1:10 000 (PGW WP) }\end{array}$ \\
\hline $\begin{array}{l}\text { Pokrycie terenu } \\
\text { Land cover }\end{array}$ & $\begin{array}{l}\text { Baza Danych Obiektów Ogólnogeograficznych (BDOO) } \\
\text { Database of General-geographical Objects }\end{array}$ \\
\hline $\begin{array}{l}\text { Suma opadów atmosferycznych z lat 1970-2000 } \\
\text { Total precipitation during 1970-2000 }\end{array}$ & Worldclime 2; http://worldclim.org; Fick, Hijmans, 2017 \\
\hline
\end{tabular}

skali 1:10 000, pochodzącej z zasobów Państwowego Gospodarstwa Wodnego Wody Polskie (PGW WP). Natomiast informacje o pokryciu terenu pozyskano z Bazy Danych Obiektów Ogólnogeograficznych (BDOO), należącej do Państwowego Zasobu Geodezyjnego i Kartograficznego (PZGiK). W obliczeniach wzięto również pod uwagę średnią sumę opadów w latach 1970-2000, pozyskaną z globalnych danych klimatycznych WorldClim (Fick, Hijmans, 2017), która określa zmienność rozmieszczenia przestrzennego 30-letniej średniej sum opadów atmosferycznych. Przy czym opady atmosferyczne zostały potraktowane w obliczeniach nie jako czynnik aktywny, lecz bierny.

\section{METODYKA}

Podatność osuwiskową obliczano trzema metodami statystycznymi, stosując różne warianty, co pozwoliło zweryfikować ich przydatność. Pierwszą zastosowaną metodą był wskaźnik osuwiskowości powierzchniowej (van Westen, 1993). W metodzie tej wynik wyraża procentowo stosunek powierzchni osuwisk do powierzchni całego obszaru objętego klasą czynnika biernego. Jako drugą zastosowano metodę indeksową (landslide index method; Brabb, 1984; van Westen, 1993), a jako trzecią metodę wag przesłanek (Weight of Evidence - WoE; van Westen, 1993; Mrozek i in., 2004; Mrozek, 2009), opierającą się na teorii warunkowego prawdopodobieństwa Beyesa (Bonham-Carter i in., 1989). Metodę indeksową oraz wag przesłanek zalicza się do dwuwymiarowych analiz obliczania podatności osuwiskowej (bivariate analisis; Alleotti, Chowdhury, 1999; Mrozek, 2009; Małka, 2018).

Wpływ poszczególnych czynników biernych na powstawanie osuwisk przeliczano w różnych wariantach - to znaczy zarówno względem całych powierzchni wszystkich osuwisk, tylko osuwisk aktywnych, centroid powierzchni osuwisk, jak również tylko względem skarp osuwiskowych, które bezspornie są świadectwem występowania na powierzchni terenu stref oderwania w masywie skalnym (ryc. 1). Każdorazowo dla przyjętego wariantu obliczeń korelowano ze sobą wszystkie czynniki bierne w celu wyeliminowania zmiennych zależnych od siebie. Podatność osuwiskową tworzono sumując obliczone indeksy lub wskaźniki czynników biernych, przy czym w większości przypadków dokonywano wagowania wpływu czynników biernych na podatność osuwiskową, stosując: wagowanie procentowe wpływu, metodę wskaźników głównych (participial components) oraz analizę czynników (factor analisis). Wagowanie takie różnicowało wpływ czynników biernych na podatność osuwiskową, tworząc modele zdominowane przez część z nich. Ostatecznie obliczono dla wymienionych wariantów 56 różnych modeli podatności osuwiskowej, spośród których, poprzez analizę krzywych sukcesu, wybrano najlepszy z nich.

Najbardziej wiarygodny procentowy rozkład powierzchni osuwisk względem wartości podatności osuwiskowej otrzymano dla modelu obliczonego metodą WoE, wykorzystując skarpy osuwiskowe z uwzględnieniem litologii, tektoniki, spadków i ekspozycji stoków oraz pokrycia terenu, bez wagowania wpływu czynników biernych.

W celu uzyskania lepszej czytelności wyników podatność osuwiskową Polski sklasyfikowano w pięciu przedziałach (ryc. 2). Dokonano tego poprzez analizę histogramu rozkładu podatności osuwiskowej z uwzględnieniem lokalizacji osuwisk.

\section{PODATNOŚĆ OSUWISKOWA POLSKI}

$\mathrm{Na}$ podstawie danych o podatności osuwiskowej można stwierdzić, że prawdopodobieństwo występowania osuwisk dotyczy powierzchni ok. 15\% obszaru Polski (ryc 2). Mogłoby się zatem wydawać, że na powierzchni ok. 85\% kraju problem osuwisk jest statystycznie nieistotny. Nie oznacza to jednak, że osuwiska wcale nie mogą wystąpić na tych terenach. Bardzo często ruchy masowe są rejestrowane np. w różnego rodzaju nasypach antropogenicznych, które w skali obliczeniowej nie mogły być brane pod uwagę. Bardzo duża i duża podatność osuwiskowa obejmuje łącznie nieco ponad 6\% powierzchni kraju. Szczególnie podatne są Karpaty (ryc. 2, 3), niektóre regiony Sudetów i Wyżyn Polskich (ryc. 4) oraz strefy przykorytowe większych rzek (ryc. 5). Dużą i bardzo dużą podatnością osuwiskową charakteryzują się też strefy krawędziowe wysoczyzn morenowych (ryc. 6).

Odrębnie potraktowano osuwiska, które już dziś stanowią realne zagrożenie, od tych, które mogą zagrażać w przyszłości. Porównując lokalizację osuwisk z mapą podatności osuwiskowej stwierdzono, że $96 \%$ powierzchni objętej osuwiskami znajduje się w strefach o bardzo dużej i dużej podatności osuwiskowej. Tylko $0,32 \%$ powierzchni osuwisk znajduje się w strefach statystycznie nieistotnych dla ruchów masowych. Najbardziej podatne na osunięcia 


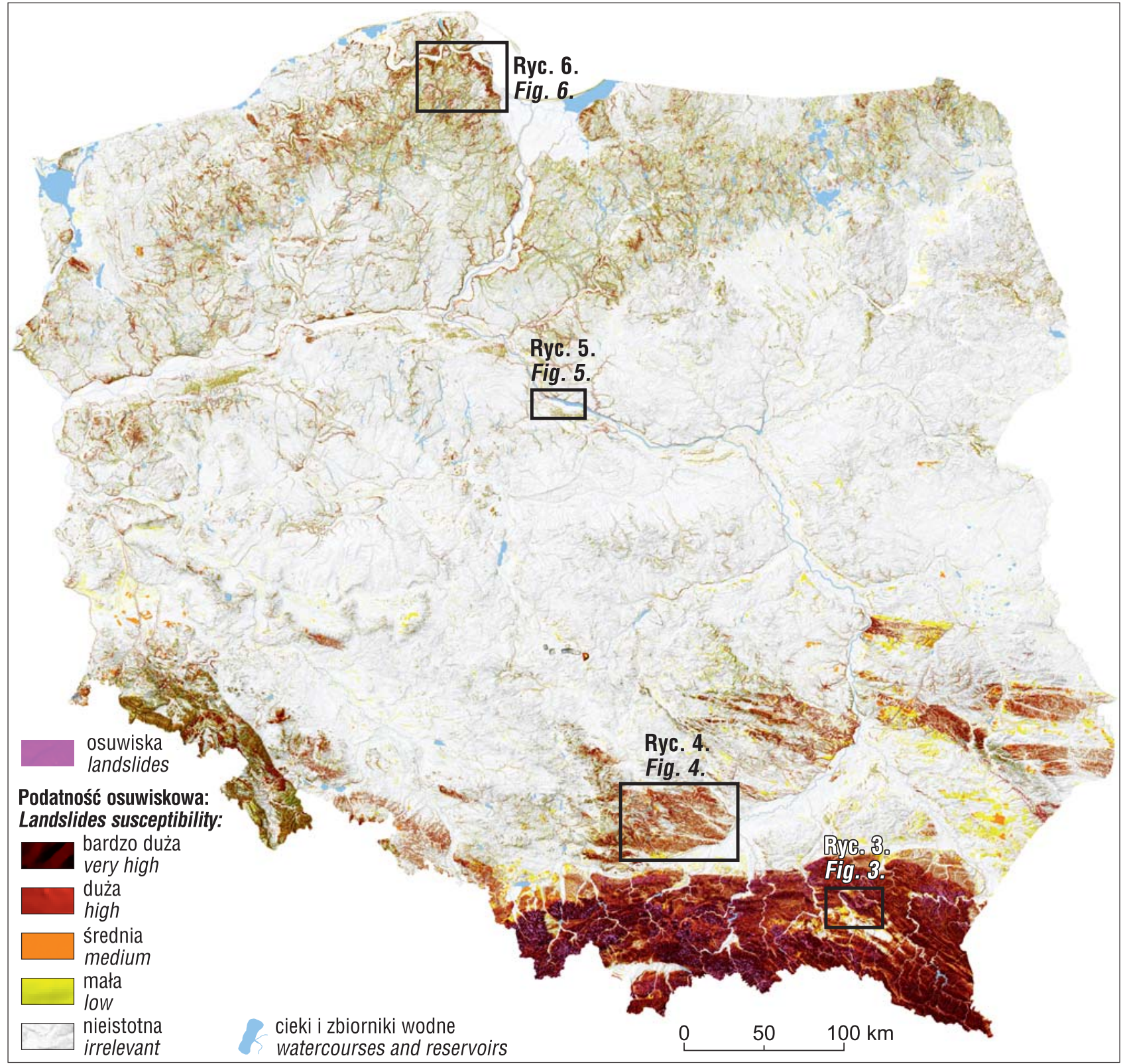

Ryc. 2. Podatność osuwiskowa Polski

Fig. 2. Landslide susceptibility of Poland

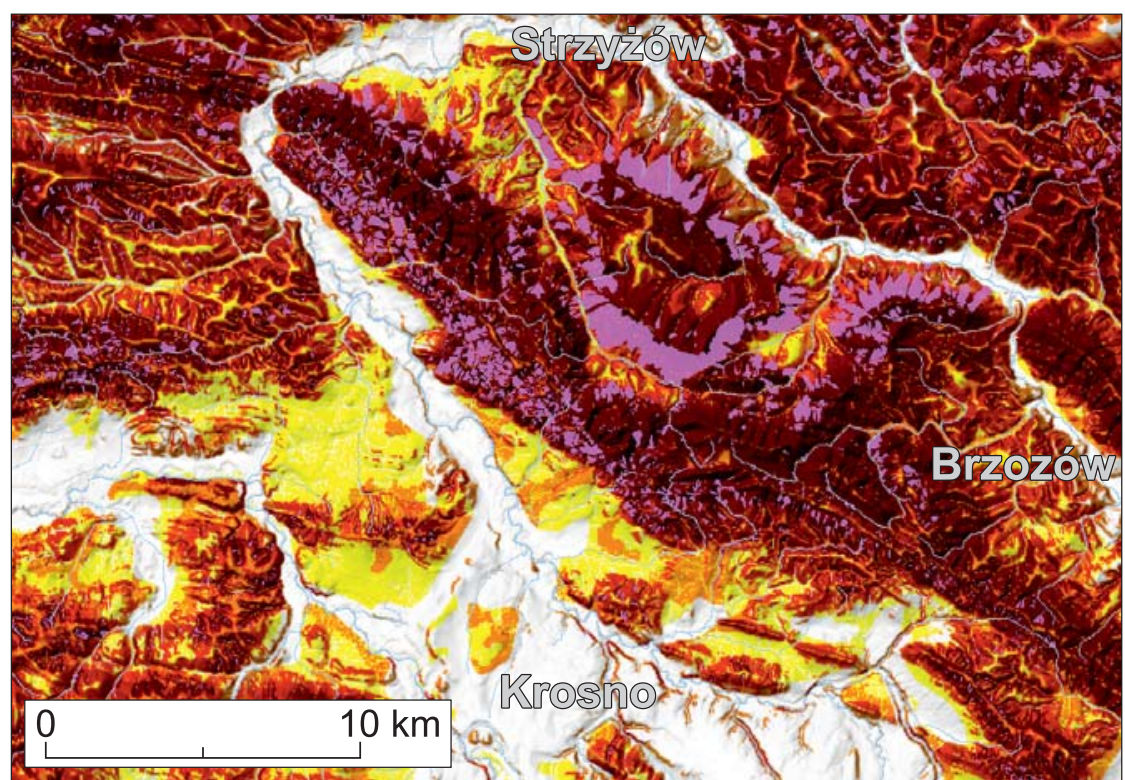

Ryc. 3. Podatność osuwiskowa Polski na obszarze Pogórza Strzyżowskiego. Objaśnienia na ryc. 2

Fig. 3. Landslide susceptibility of Poland - Strzyżów Foothills area. For explanation see Fig. 2 


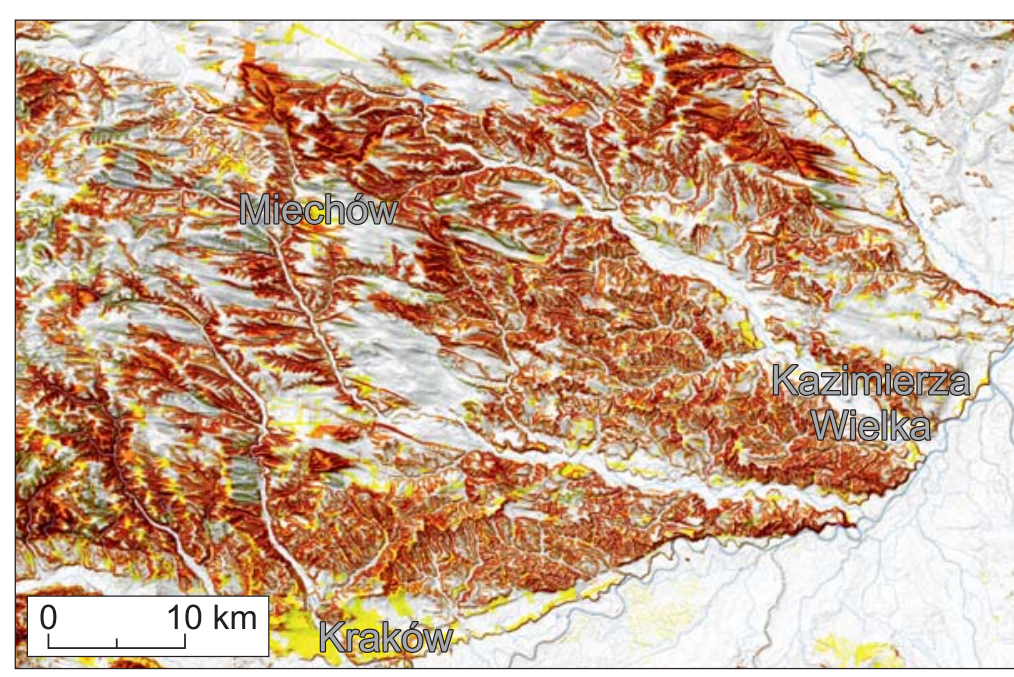

Ryc. 4. Podatność osuwiskowa Polski na obszarze Wyżyny Miechowskiej. Objaśnienia na ryc. 2

Fig. 4. Landslide susceptibility of Poland - Miechów Upland area. For explanation see Fig. 2

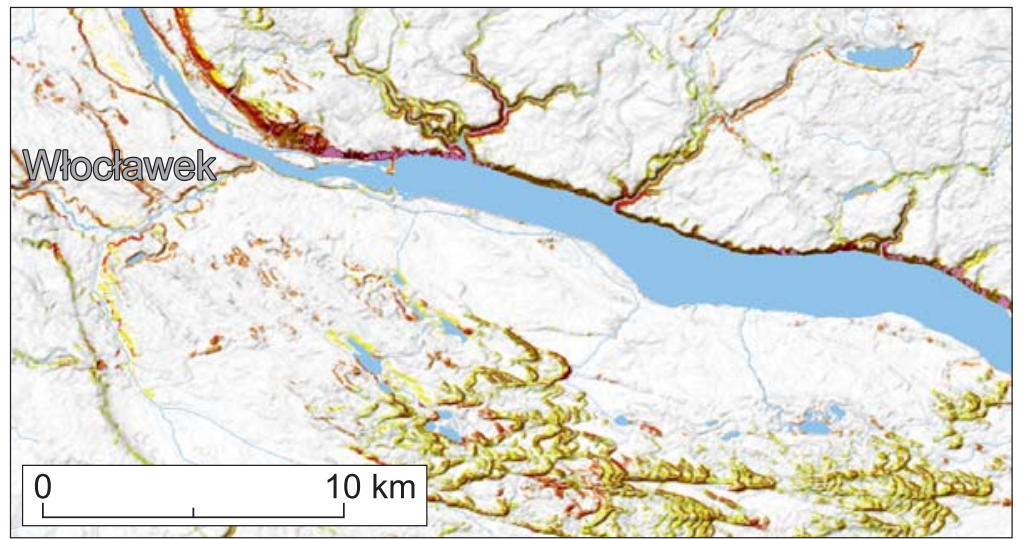

Ryc. 5. Podatność osuwiskowa Polski w okolicach Włocławka.

Objaśnienia na ryc. 2

Fig. 5. Landslide susceptibility of Poland - surroundings of Włocławek. For explanation see Fig. 2

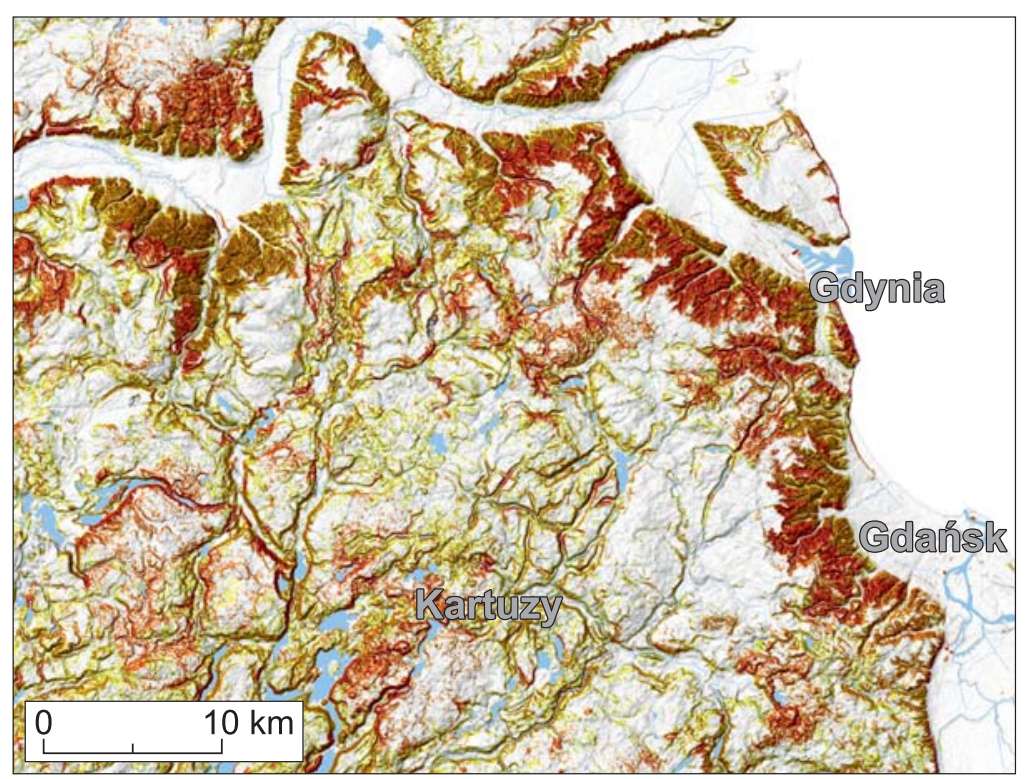

Ryc. 6. Podatność osuwiskowa Polski na Pojezierzu Kaszubskim. Objaśnienia na ryc. 2

Fig. 6. Landslide susceptibility of Poland - Kashubian Lake District area. For explanation see Fig. 2 są obszary województw: małopolskiego, podkarpackiego, śląskiego, dolnośląskiego, świętokrzyskiego oraz lubelskiego.

Spośród czynników biernych największy wpływ na osuwiska w Polsce mają spadki terenu w przedziale $9-30^{\circ}$. Zagrożenia osuwiskowe na stokach potęgują się w strefach dyslokacji tektonicznych oraz w miejscach występowania w podłożu skał fliszowych. Duże znaczenie osuwiskotwórcze mają również występujące w podłożu skały wulkanogeniczne, wapienie współwystępujące z łupkami, margle, lessy, iły oraz gliny. Na wzrost podatności osuwiskowej, chociaż w mniejszym stopniu, mają także wpływ granitoidy, cieszynity oraz nasypy antropogeniczne. W skali Polski ekspozycja stoków i zboczy ma niewielkie znaczenie. Spośród wszystkich klas pokrycia terenu jedynie zabudowa wpływa w niewielkim stopniu na wzrost podatności osuwiskowej.

\section{PODSUMOWANIE}

Mapa podatności osuwiskowej Polski pokazuje rozkład potencjalnych zagrożeń ruchami masowymi, przy czym należy pamiętać, że najbardziej zagrożone są obszary, gdzie osuwiska już wystąpiły. Obliczona podatność osuwiskowa Polski potwierdza możliwość uruchamiania się osuwisk w obszarach pozakarpackich - osuwiska mogą licznie występować w Sudetach (Sikora, Wojciechowski, 2019), Górach Świętokrzyskich, ale również na wszystkich Wyżynach Polskich. Podatne na osuwanie są również strefy przykorytowe rzek, klify i strefy krawędziowe wysoczyzn morenowych.

Mapa podatności osuwiskowej Polski w sposób orientacyjny obrazuje zagrożenia, jakie mogą wynikać z obecności ruchów masowych. Porównanie mapy podatności z bazą danych obiektów topograficznych (BDOT) w skali 1:10 000, znajdującą się w Państwowym Zasobie Geodezyjnym i Kartograficznym, udostępnianym przez głównego geodetę kraju, pokazuje, że na obszarze podatnym osuwiskowo, który stanowi $15 \%$ powierzchni kraju, jest zlokalizowanych 1051989 budynków, z czego ponad 570000 stanowią budynki mieszkalne. W obszarach podatnych na osunięcia znajduje się ponad 25000 zabudowań przemysłowych, natomiast budynków użyteczności publicznej jest 9520. Przez obszary te przebiega ok. $555 \mathrm{~km}$ dróg krajowych, 1077 km dróg wojewódzkich, 5448 km dróg powiatowych i gminnych oraz $585 \mathrm{~km}$ linii kolejowych. Z tego ogólnikowego i prostego zestawienia wynika, że w Polsce znajduje się bardzo duża liczba obiektów wrażliwych, które w przyszłości mogą być w jakimś stopniu zagrożone przez osuwiska. Ze względu na małą skalę danych wejściowych mapa ta nie może być wykorzystywana do planowania przestrzennego - ma natomiast duże znaczenie poglądowe, a także inne ważne zastosowanie, ponieważ to na jej podstawie są szacowane 
koszty planowanych prac inwentaryzacyjnych osuwisk oraz ich weryfikacja w poszczególnych jednostkach administracyjnych.

Mapa podatności osuwiskowej Polski jest corocznie aktualizowana. Wraz ze wzrostem liczby rozpoznanych osuwisk wzrasta jej jakość i dokładność. Dalsze podnoszenie jakości i szczegółowości tej mapy mogą w przyszłości umożliwić coraz lepsze i dokładniejsze dane wejściowe oraz dalszy rozwój metod obliczania podatności osuwiskowej.

Autor składa podziękowania współpracownikom za liczne dyskusje związane $\mathrm{z}$ problemami ujętymi w publikacji oraz Recenzentom za poświęcony czas oraz cenne uwagi, które pozwoliły udoskonalić treść i formę artykułu.

\section{LITERATURA}

ALEOTII P., CHOWDHURY R. 1999 - Landslide hazard assessment: summary, review and new perspectives. Bull. Eng. Geol. Env., 58: 21-44. BOBER L. 1984 - Rejony osuwiskowe w polskich Karpatach fliszowych i ich związek z budową geologiczną. Biul. Inst. Geol., 340. Z badań geologicznych w Karpatach, 23: 115-153.

BOBER L., THIEL K., ZABUSKI L. 1997 - Zjawiska osuwiskowe w polskich Karpatach fliszowych. Geologiczno-inżynierskie właściwości wybranych osuwisk. Wyd. IBW PAN, Gdańsk.

BONHAM-CARTER G.F., AGTERBERG F.P., WRIGHT D.F. 1989 Weight of evidence modeling: a new approach to mapping mineral potential. [W:] Agterberg F.P., Bonham-Carter G.F. (red.), Statistical Applications in the Earth Sciences. Geological Survey of Canada: 171-183.

BRABB E.E. 1984 - Innovative approaches to landslides hazard and risk mapping. Proceedings of the IV International Symposium on Landslides, Toronto, 1: 307-323.

BRONOWSKI B., CHYBIORZ R., JURA D. 2016 - Landslide susceptibility mapping in the Beskid Niski Mts., Western Carpathians (Dukla commune, Poland). Geol. Quart., 60 (3): 586-596.

DŁUGOSZ M. 2011 - Podatność stoków na osuwanie w polskich Karpatach fliszowych. Pr. Geogr., 230: 112.

FICK S.E., HIJMANS R.J. 2017 - Worldclim 2: New 1-km spatial resolution clime surfaces for global and areas. Int. J. Climatol., 37: 4302-4315. GRABOWSKI D. (red.) 2008 - Przeglądowa mapa osuwisk i obszarów predysponowanych do występowania ruchów masowych w skali 1:50 000 dla Polski pozakarpackiej. Arch. Państw. Inst. Geol. - PIB w Warszawie. GRABOWSKI D., MARCINIEC P., MROZEK T., NESCIERUK P., RĄCZKOWSKI W., ZIMNAL Z. 2008 - Instrukcja opracowania Mapy osuwisk i terenów zagrożonych ruchami masowymi w skali 1:10 000. Państw. Inst. Geol.: 92.

GÜNTHER A., VAN DEN EECKHAUT M., MALET J.P., REICHENBACH P., HERVÁS J. 2014 - Climate-physiographically differentiated Pan-European landslide susceptibility assessment using spatial multi-criteria evaluation and transnational landslide information. Geomorphology, 224: 69-85.

HOLEC J., BEDNARIK M., ŠABO M., MINÁR J., YILMAZ I., MARCHALKO M. 2013 - A small-scale landslide susceptibility assessment for the territory of Western Carpathians. Natural Hazard, 69: 1081-1107.

HONG Y., ADLER R., HUFFMAN G. 2007 - Use of satellite remote sensing data in the mapping of global landslide susceptibility. Natural Hazards, 43: $245-256$.

http://geoportal.pgi.gov.pl/portal/page/portal/SOPO (31.12.2018 r.) https://www.pgi.gov.pl/krakow/oddzial-karpacki/sep1-krak/karpackie-osuwiska.html

KAMIENIARZ S., WÓDKA M., WOJCIECHOWSKI T., WÓJCIK A., 2016 - Podatność osuwiskowa rejonu planowanego zbiornika Świnna Poręba. Wyzwania Polskiej Geologii, 3. Polski Kongres Geologiczny, 14-18 września 2016 r. we Wrocławiu: 134-136.

KAMIŃSKI M. 2007 - Mapa podatności osuwiskowej - studium z regionu Jodłówki (Pogórze Dynowskie). Prz. Geol., 55: 779-784.

KAMINSKI M. 2012 - Mapa podatności osuwiskowej w skali regionalnej - przykłady z Doliny Sanu na Pogórzu Dynowskim. Biul. Państw. Inst. Geol., 452: 109-118

KIRSCHBAUM D., STANLEY T. 2018 - Satellite-Based Assessment of Rainfall-Triggered Landslide Hazard for Situational Awareness. Earth's Future, 6: 505-523.

MAŁKA A. 2015 - Modelowanie podatności osuwiskowej z zastosowaniem metody indeksowej i wysokorozdzielczych danych z lotniczego skaningu laserowego (LIDAR) na obszarze Gdańska. Prz. Geol., 63 (5): 301-311.
MAŁKA A. 2018 - Podatność i ryzyko osuwiskowe w obszarach rzeźby młodoglacjalnej, przeobrażonej antropogenicznie, na terenie Gdyni. Pr. doktorska. Arch. Państw. Inst. Geol. -PIB, Gdańsk.

MARKS L., BER A., GOGOŁEK W., PIOTROWSKA K. (red.) 2006 Mapa geologiczna Polski 1:500 000. Państw. Inst. Geol.

MROZEK T. 2009 - Ocena zagrożenia osuwiskowego i związanego z nim ryzyka przy wykorzystaniu metod GIS na przykładzie okolic Szymbarku, Beskid Niski. Pr. doktorska. Arch. PIG Kraków.

MROZEK T. 2013 - Zagrożenie i ryzyko osuwiskowe w rejonie Szymbarku (Beskid Niski). Pr. Państw. Inst. Geol., 199: 40.

MROZEK T., LASKOWICZ I., ZABUSKI L., KULCZYKOWSKI M., ŚWIDZIŃSKI W. 2016 - Landslide susceptibility and risk assessment in a non-mountainous region - a case study of Koronowo, northern Poland. Geol. Quart., 60 (3): 758-769.

MROZEK T., POLI S., STERLACCHINI S., ZABUSKI L. 2004 Landslide Susceptibility Assessment: A Case Study from the Beskid Niski Mts., Carpathians, Poland. [W:] Graniczny M., Piątkowska A., Balabanis P. (red.), Proceedings of the Conference "Risks Caused by the Geodynamic Phenomena in Europe", Polish Geol. Inst. Sp. Pap., 15: 13-18.

NADIM F., KJEKSTAD O., PEDUZZI P., HEROLD C., JAEDICKE C. 2006 - Global landslide and avalanche hotspots. Landslides, 3: 159-173. PAWLUSZEK K., BORKOWSKI A. 2017 - Impact of DEM-derived factors and analytical hierarchy process on landslide susceptibility mapping in the region of Rożnów Lake, Poland. Nat. Haz., 86: 919-952.

POPRAWA D., RĄCZKOWSKI W. 2003 - Osuwiska Karpat. Prz. Geol., 51 (8): 685-692.

RĄCZKOWSKI W. 2007 - Zagrożenia osuwiskowe w polskich Karpatach. Prz. Geol., 55: 638.

RUBINKIEWICZ J., BIEL A., KACZOROWSKI J., KARWACKI K., RYCIO E., KOŁECKI T., JURYS L. 2015 - Mapa osuwisk i terenów zagrożonych ruchami masowymi w skali 1:10 000, gm. Stryszawa, pow. suski, woj. małopolskie; http://mapa.osuwiska.pgi.gov.pl

SIKORA R., WOJCIECHOWSKI T. 2019 - Osuwiska w Sudetach. Prz. Geol., 67: 360-368.

SIKORA R., WOJCIECHOWSKI T., PIOTROWSKI A., TOMASZCZYK M. 2017 - Geological condition of landslides occurrence in the Bardzkie Mountains and adjacent areas (Sudetes, SW Poland). World Landslide Forum, 4WLF, Lubliana. Poster; https://wlf4.fgg.uni-lj.si/ wp-content/uploads/2017/05/WLF4-Local-Proceedings-and-Programmewith-posters.pdf

VAN DEN EECKHAUT M., HERVÁS J., JAEDICKE C., MALET J.P., MONTANARELLA L., NADIM F. 2012 - Statistical modelling of Europe - wide landslide susceptibility using limited landslide inventory data. Landslides, 9: 357-369.

VAN WESTEN C.J. 1993 - Application of Geographic Information Systems to Landslide Hazard Zonation. ITC Publication No. 14, International Institute for Aerospace Survey and Earth Science (ITC), Enschede: 245.

VARNES D.J. 1978 - Slope movement types and processes. [W:] Schuster R., Krizek R. (red.), Landslides - Analysis and control, Transportation Research Board, NRC Washington, D.C., Sp. Rep., 176: 12-33. WILDE M., GÜNTHER A., REICHENBACH P., MALET J.P., HERVÁS J. 2018 - Pan-European landslide susceptibility mapping: ELSUS Version 2, J. Maps, 14 (2): 97-104.

WHO, 2010 - Poland: Landslide Hazard Distribution Map. World Health Organization; http://data.euro.who.int/e-atlas/europe/countries/poland/poland-landslide-map.html

WOJCIECHOWSKI T. 2008 - Podatność osuwiskowa zboczy w Wieliczce. Pr. Nauk. Inst. Gór. Polit. Wroc., 122, ser. 51: 247-256.

WOJCIECHOWSKI T. 2010 - Geologiczna analiza osuwisk z wykorzystaniem satelitarnej interferometrii radarowej na przykładzie rejonu Nowego Sacza. Pr. doktorska. Arch. WNoZ UŚ, Sosnowiec.

WOJCIECHOWSKI T., WÓJCIK A. 2015 - Podatność i zagrożenia osuwiskowe na fragmencie wschodniego obrzeżenia Jeziora Rożnowskiego w świetle analiz różnicowych LIDAR. Ogólnopolska Konferencja O!SUWISKO, 19-22 maja 2015, Wieliczka. Mat. konf.: 81-82.

WOJCIECHOWSKI T., KAMIENIARZ S., MICHALSKI A., WÓJCIK A., KUŁAK M. 2017 - Podatność osuwiskowa Polski - stan na 2017 rok. 6. Ogólnopolskie Sympozjum Wspótczesne problemy geologii inżynierskiej w Polsce, 17-20.10.2017 r., Rzeszów. Książka abstraktów: 77. WOJCIECHOWSKI T., MROZEK T., LASKOWICZ I., KUŁAK M., 2015 - Podatność osuwiskowa Polski. Poster. Ogólnopolska Konferencja O!suwisko, 19-22 maja 2015, Wieliczka. Mat. konf. Państw. Inst. Geol. -PIB: 119-120.

WÓJCIK A., WOJCIECHOWSKI T. 2016 - Osuwiska jako jeden z ważniejszych elementów zagrożeń geologicznych w Polsce. Prz. Geol., 64 (9): 701-709.

WÓJCIK A., RĄCZKOWSKI W., WOJCIECHOWSKI T. 2017 - Osuwiska. [W:] Nawrocki J., Becker A. (red) - Atlas geologiczny Polski. Państw. Inst. Geol. -PIB: 144-145.

ZABUSKI L., THIEL K., BOBER L. 1999 - Osuwiska we fliszu Karpat polskich: Geologia, modelowanie, obliczenia stateczności. Wyd. IBW PAN, Gdańsk: 171. 